\title{
IAMJ
}

INTERNATIONAL

AYURVEDIC

MEDICAL JOURNAL

ISSN: 2320-5091

Impact Factor: 6.719

\section{EVALUATION OF THE EFFICACY OF KUSHMANDABEEJADI LEPA AGAINST SIGRUPUNARNAVADI LEPA IN WASP STING - A COMPARATIVE CLINICAL TRIAL}

\section{$\underline{\text { Vijitha Vijayan }}$}

Assistant Professor, Department of Agadtantra, Krishna Ayurveda Medical College, Varnama, Vadodara, Gujarat, India

Corresponding Author: vijithav29@gmail.com

https://doi.org/10.46607/iamj0309032021

(Published online: March 2021)

Open Access

(C) International Ayurvedic Medical Journal, India 2021

Article Received: 02/03/2021 - Peer Reviewed: 08/03/2021 - Accepted for Publication: 17/03/2021

Check for updates

\begin{abstract}
Wasp stings are common especially during the warmer months when people are outside for longer periods of time. They are equipped with a stinger for self-defence. A wasp's stinger contains venom that is transmitted to humans during a sting. Local manifestations following stings are common and usually life-threatening anaphylaxis may occur. Most of the cases involve one or a few stings where only local symptoms without any serious allergic reactions. In such cases Vishaghna lepas (antitoxic topical applications) can be used as it nullifies the harmful or poisonous effects along with medicinal intake. Here, in this study, the efficacy of Kushmandabeejadi lepa churna, mentioned in Kriyakoumudi (traditional book on toxicology) for wasp sting is studied by administering it along with another widely practiced classical preparation. Aim and Objectives- The study was conducted to study the efficacy of Kushmandabeejadi lepa against Sigrupunarnavadi lepa along with Dasanga agada in the management of Wasp sting Methods- A clinical study with 20 participants fulfilling the diagnostic and inclusion criteria was selected alternately and assigned in to two groups. Group 1(trial group) received Kushmanadabeejadi lepa churna and Group 2(control group) received Sigrupunarnavadi lepa churna five times daily for a period of three days, both as external application. Fourth day was observatory period and assessment was done on fifth day. In both groups, Dasanga agada was used as common internal medicine. Results-The outcome variables - pain, itching, erythema and swelling were assessed for the change in mean score values. Data were analysed statistically using Mann-Whitney U Test and Wilcoxon Signed Rank Test. The result obtained was significant in relieving the cardinal symptoms of wasp sting Conclusion- The overall effect shows that both the treatments individually
\end{abstract}


were significant in the management of wasp sting and Kushmandabeejadi lepa is equally effective in managing the signs and symptoms produced by wasp sting when compared with Sigrupunarnavadi lepa.

Keywords: Kushmandabeejadi Lepa; wasp sting; Sigrupunarnavadi Lepa; Vishaghna Lepa, Dasanga agada

\section{INTRODUCTION}

Although different types of insects are able to inflict poisonous bites or stings, the insects most likely to cause medical problems are bees and wasps. Wasp stings are a real hazard and worth some research. Most times it may cause only minor medical problems. But it may also become fatal due to anaphylactic reactions. This insect abounds in many parts of India and other tropical and temperate regions, especially during flowering season. Wasp stings are very common especially in population living in proximity of forest areas all over the world.

Most of the cases involve one or a few stings where only local symptoms are developed without any serious allergic reactions. In such cases, Vishaghna lepas can be used as it nullifies the harmful or poisonous effects along with medicinal intake. In Vishachikitsa (toxicology), lepas (topical applications) are considered as first and prime treatment aspect ${ }^{1}$. Commonly used internal medicine in Wasp sting is Dasanga agada ${ }^{2}$ as it is indicated in all types of keetavisha (insect poisoning). Sigrupunarnavadi lepa ${ }^{3}$ is scientifically proven in keetavisha and is traditionally used by vishavaidyas (traditional toxicologists) in Kerala to treat Wasp sting. But the number of ingredients in Sigrupunarnavadi lepa makes it a costly one which invites for the need for simpler preparation.

Kushmandabeejadi lepa ${ }^{4}$ yoga mentioned in Kriyakoumudi chapter Keetadi vishaprakarana is indicated for wasp sting. Kushmanda (Benincasa hispida) being Vata-pitha shamana ${ }^{5,6}$ where Keetavishas are generally having the same Dosha predominance ${ }^{7}$ along with Haridra (Curcuma longa) possessing Vishahara (antitoxic) property can be effective in wasp sting. Here in this study, an attempt is made to find out the efficacy of Kushmandabeejadi lepa which is cost effective and easily available.

\section{Materials and Methods}

A treatment modality based on the principles set in classical text and Keraleeya Vishagranthas (ancient toxicology books of Kerala) was developed incorporating procedures and medicines described in the treatment of wasp sting and is applied in this clinical trial. The whole plan of study was approved by Institutional Ethics Committee (IEC) prior to starting of work IEC No:-IEC/2017/11; Dated-29/03/2017. Consent form was prepared and prior consent of all the participants were obtained on the consent form. A pamphlet containing the details of the research was given to the participants.

A clinical study with 20 participants fulfilling the diagnostic and inclusion criteria was selected alternately and assigned in to two groups, age group between 16 to 60 years, attending OPD within 48 hours following wasp sting. Group 1 (trial group) received Kushmandabeejadi lepa churna and Group 2 (control group) received Sigrupunarnavadi lepa churna five times daily for a period of three days. Fourth day was observatory period and assessment were done on fifth day. In both groups, Dasanga agada was used as common internal medicine.

\begin{tabular}{|c|c|c|}
\hline & Group 1 (trial group) & Group 2 (control group) \\
\hline Drug internal & Dasanga gutika & Dasanga gutika \\
\hline Dose & 2 grams twice daily & 2 grams twice daily \\
\hline Drug external & Kushmanda beejadi lepa & Sigrupunarnavadi lepa \\
\hline Medium of application & Water & Water \\
\hline Area of application & $\begin{array}{l}\text { In and around the bite site where } \\
\text { swelling and redness are seen }\end{array}$ & $\begin{array}{l}\text { In and around the bite site where swelling and } \\
\text { redness are seen }\end{array}$ \\
\hline
\end{tabular}




\section{Diagnostic Criteria}

- History of acute wasp sting

- Pain at the site of sting

- Swelling at the site of sting

- Redness at the site of sting

- Itching at the site of sting

Inclusion Criteria

- Age group between 16 to 60 years

- Diagnosed cases of wasp sting within 48 hours.

- Participants with any of the essential symptoms like pain, swelling, redness and itching.
- Participants irrespective of gender, caste, religion and economic status.

\section{Exclusion Criteria}

- All sting cases apart from Wasp sting.

- Stings over fatal areas like eyes, lips etc.

- Cases having more than one sting

- Participants presenting with complications of sting like dyspnoea and anaphylactic reactions

- Pregnant and lactating women.

- Participants with systemic diseases like DM, HTN and other systemic disorders

\section{Preparation of Drugs}

Dasanga Gulika

Table 1: Ingredients of Dasanga gulika

\begin{tabular}{|c|c|c|c|}
\hline Ingredients & Botanical name & Family & Part used \\
\hline Vacha & Acorus calamus & Araceae & Rhizome \\
\hline Hingu & Ferula narthex & Umbelliferae & Resin \\
\hline Vidanga & Embelia ribes & Myrsinaceae & Fruit \\
\hline Saindavam & Rock Salt & & Salt \\
\hline Gajapipali & Scindapsus officinalis & Piperaceae & Fruit \\
\hline Patha & Cissampelos pareira & Menispermaceae & Root \\
\hline Prativisha & Aconitum heterophyllum & Ranunculaceae & Tuberous Root \\
\hline Sundi & Zingiber officinale & Zingiberaceae & Rhizome \\
\hline Maricha & Piper nigrum & Piperaceae & Fruit \\
\hline Pippali & Piper longum & Piperaceae & Fruit \\
\hline
\end{tabular}

All the above drugs are taken in equal quantity by weight and made in to a hand-made pill of $2 \mathrm{gm}$.

\section{Kushmandabeejadi lepa churna ${ }^{4}$}

Table 2: Ingredients of Kushmandabeejadi lepa churna

\begin{tabular}{|l|l|l|l|}
\hline Drug & Botanical name & Family & Part used \\
\hline Kushmanda & Benincasa hispida & Cucurbitaceae & Seed \\
\hline Haridra & Curcuma longa & Zingiberaceae & Rhizome \\
\hline
\end{tabular}

Kushmanda Beeja and Haridra are dried and made into a very fine powder

Table 3: Ingredients of Sigrupnarnavadi lepa churna

\begin{tabular}{|l|l|l|l|}
\hline Drug & Botanical name & Family & Part used \\
\hline Sigru & Moringa olifera & Moringaceaea & Bark \\
\hline Punarnava & Boerhavia diffusa & Nyctanginaceae & Root \\
\hline Vaca & Curcuma longa & Zingiberaceae & Rhizome \\
\hline Rakta chandana & Acorus calamus & Araceae & Rhizome \\
\hline Pata & Pterocarpus santalinus & Fabaceae & Heartwood \\
\hline Iswari & Cyclea peltata & Menispermaceae & Root \\
\hline Yashtimadhu & Aristolochia indica & Aristolochiaceae & Root \\
\hline Sireesha & Glycyrrhiza glabra & Fabaceae & Stem \\
\hline Gokshura & Albizia lebbeck & Fabaceae & Bark \\
\hline All & Tribulus terrestris & Fabaceae & Seed \\
\hline
\end{tabular}

All the above drugs are taken in equal quantity by weight, dried and made into a very fine powder. 


\section{Proportion of Lepa churna with water}

Depending up on the condition and site of the sting, the amount of lepa churna needed may vary. Adequate amount of water is added to churna and made into a fine paste.

\section{Assessment Criteria}

The following Subjective and Objective parameters will be assessed using different grading and scoring methods before and after treatment.

Subjective Parameters: Local pain., Local itching Objective Parameters: Swelling., Redness/ erythema Assessment
Assessment criteria includes the 4 main cardinal symptoms, namely, pain, oedema, itching and erythema. The changes in the above said parameters will be noted at specific intervals and assessment will be done accordingly. It was recorded in the concerned CRF and evaluated systematically to draw a conclusion on the effect at individual \& comparative level for the groups by means of Mann - Whitney U test and Wilcoxon Signed Rank test. The overall relief obtained will be assessed as follows:

$100 \%$ Relief- cured, 76\% - 99\%- marked improvement, 51\%-75\%-moderate improvement, 26\%-50\% mild. $0-25 \%$ - unchanged

Table 4: Variables of Pain

\begin{tabular}{|l|l|}
\hline 0 & No pain \\
\hline 1 & Pain on pressure \\
\hline 2 & Dull continuous, not disturbing movement or functioning of the part. \\
\hline 3 & Sharp continuous, not disturbing movement or functioning of the part. \\
\hline 4 & Sharp continuous, Patient is unable to move the part, normal routine including sleep is disturbed \\
\hline
\end{tabular}

Table 5: Variables of Erythema

\begin{tabular}{|l|l|}
\hline 0 & No redness \\
\hline 1 & Diffused, only at the point of sting \\
\hline 2 & Diffused, involving the surrounding area up to $5 \mathrm{~cm}$ \\
\hline 3 & Marked, involving the surrounding area up to $5 \mathrm{~cm}$ \\
\hline 4 & Marked, involving area more than $5 \mathrm{~cm}$ \\
\hline
\end{tabular}

Table 6: Variables of swelling

\begin{tabular}{|l|l|}
\hline 0 & No Swelling \\
\hline 1 & Below $0.5 \mathrm{~cm}$ increase in circumference \\
\hline 2 & Up to $0.5 \mathrm{~cm}-1 \mathrm{~cm}$ increase in circumference \\
\hline 3 & $1 \mathrm{~cm}-1.5 \mathrm{~cm}$ increase in circumference \\
\hline 4 & more than $1.5 \mathrm{~cm}$ increase in circumference \\
\hline
\end{tabular}

Table 7: Variables of Itching

\begin{tabular}{|l|l|}
\hline 0 & no itching \\
\hline 1 & occasional itching \\
\hline 2 & continuous itching \\
\hline 3 & continuous itching disturbing daily work \\
\hline 4 & continuous itching disturbing sleep \\
\hline
\end{tabular}

Statistical Analysis - Pain, erythema, swelling and itching changes were assessed on comparing their values after applying Mann-Whitney U test and Wilcoxon signed-rank test.
Results: Table no. 8 shows that, according to age, out of 40 participants $45 \%$ were in the age group of $16-$ 30 years, $25 \%$ were in the age group of 31- 45 years.30\% were in the age group of $46-60$ years. $(n=40)$. 
Table no. 9 shows that according to the time of the sting, out of 40 participants, $2.5 \%$ had a sting in between 12 am and 6 am $72.5 \%$ had a sting in between $6.01 \mathrm{am}$ and $6 \mathrm{pm}$ and $25 \%$ had a sting in between
$6.01 \mathrm{pm}-11.59 \mathrm{pm}$. Table no: 10 shows distribution of 40 participants according to their domicile, $32.5 \%$ of participants are from rural area and $67.5 \%$ are from urban area.

Table 8: Distribution of 40 participants according to age

\begin{tabular}{|l|l|l|l|l|l|l|}
\hline \multirow{2}{*}{ Age } & \multicolumn{2}{|l|}{ Group I $(\mathrm{n}=20)$} & \multicolumn{2}{l|}{ Group II $(\mathrm{n}=20)$} & \multicolumn{2}{l|}{ Total $(\mathrm{n}=40)$} \\
\cline { 2 - 7 } & No & $\%$ & No & $\%$ & No & $\%$ \\
\hline $16-30$ & 9 & 45 & 9 & 45 & 18 & 45 \\
\hline $31-45$ & 3 & 15 & 7 & 35 & 10 & 25 \\
\hline $46-60$ & 8 & 40 & 4 & 20 & 12 & 30 \\
\hline
\end{tabular}

Table 9: Distribution of 40 participants according to the time of sting

\begin{tabular}{|l|l|l|l|l|l|l|}
\hline \multirow{2}{*}{ Time of sting } & \multicolumn{2}{l|}{ Group I $(\mathrm{n}=20)$} & Group II $(\mathrm{n}=20)$ & \multicolumn{2}{l|}{ Total $(\mathrm{n}=40)$} \\
\cline { 2 - 7 } & No & $\%$ & No & $\%$ & No & $\%$ \\
\hline 12am-6am & 1 & 5 & 0 & 0 & 1 & 2.5 \\
\hline $6.01 \mathrm{am}-6 \mathrm{pm}$ & 15 & 75 & 14 & 70 & 29 & 72.5 \\
\hline $6.01 \mathrm{pm}-11.59 \mathrm{pm}$ & 4 & 20 & 6 & 30 & 10 & 25 \\
\hline
\end{tabular}

Table 10: Distribution of 40 participants according to domicile

\begin{tabular}{|l|l|l|l|l|l|l|}
\hline \multirow{2}{*}{ Domicile } & Group I $(\mathrm{n}=20)$ & Group II $(\mathrm{n}=20)$ & \multicolumn{2}{l|}{ Total $(\mathrm{n}=40)$} \\
\cline { 2 - 7 } & No & $\%$ & No & $\%$ & No & $\%$ \\
\hline Rural & 9 & 45 & 4 & 20 & 13 & 32.5 \\
\hline Urban & 11 & 55 & 16 & 80 & 27 & 67.5 \\
\hline
\end{tabular}

Table 11: Comparison of Effectiveness of decrease in pain

\begin{tabular}{|c|c|c|c|c|c|c|c|}
\hline \multirow{2}{*}{\multicolumn{2}{|c|}{ Decrease in Pain (in Grade) }} & \multicolumn{2}{|l|}{ Trail } & \multicolumn{2}{|c|}{ Control } & \multirow[t]{2}{*}{$\mathrm{Z} \$$} & \multirow[t]{2}{*}{$\mathrm{p}$} \\
\hline & & Count & Percent & Count & Percent & & \\
\hline \multirow[t]{3}{*}{$3^{\text {rd day }}$} & 1 & 5 & 25.0 & 7 & 35.0 & \multirow[t]{3}{*}{0.28} & \multirow[t]{3}{*}{0.777} \\
\hline & 2 & 12 & 60.0 & 9 & 45.0 & & \\
\hline & 3 & 3 & 15.0 & 4 & 20.0 & & \\
\hline \multirow[t]{4}{*}{$5^{\text {th }}$ day } & 1 & 1 & 5.0 & 0 & 0.0 & \multirow[t]{4}{*}{0.8} & \multirow[t]{4}{*}{0.425} \\
\hline & 2 & 10 & 50.0 & 9 & 45.0 & & \\
\hline & 3 & 7 & 35.0 & 8 & 40.0 & & \\
\hline & 4 & 2 & 10.0 & 3 & 15.0 & & \\
\hline
\end{tabular}

Table 12: Comparison of Effectiveness of Erythema

\begin{tabular}{|c|c|c|c|c|c|c|c|}
\hline \multicolumn{2}{|c|}{ Erythema } & \multicolumn{2}{|l|}{ Trail } & \multicolumn{2}{|c|}{ Control } & \multirow[t]{2}{*}{$\mathrm{Z} \$$} & \multirow[t]{2}{*}{$\mathrm{P}$} \\
\hline & & Count & Percent & Count & Percent & & \\
\hline \multirow[t]{3}{*}{$3^{\text {rd }}$ day } & No redness & 12 & 60.0 & 16 & 80.0 & \multirow[t]{3}{*}{1.28} & \multirow[t]{3}{*}{0.199} \\
\hline & Diffused, only at the point of sting & 7 & 35.0 & 3 & 15.0 & & \\
\hline & Diffused, involving the surrounding area up to $5 \mathrm{~cm}$ & 1 & 5.0 & 1 & 5.0 & & \\
\hline \multirow[t]{3}{*}{$5^{\text {th }}$ day } & No redness & 20 & 100.0 & 20 & 100.0 & \multirow[t]{3}{*}{0} & \multirow[t]{3}{*}{1.000} \\
\hline & Diffused, only at the point of sting & 0 & 0.0 & 0 & 0.0 & & \\
\hline & Diffused, involving the surrounding area up to $5 \mathrm{~cm}$ & 0 & 0.0 & 0 & 0.0 & & \\
\hline
\end{tabular}


Table 13: Comparison of Effectiveness of Swelling Swelling

$3^{\text {rd }} \quad$ No swelling

day Below $0.5 \mathrm{~cm}$ increase in circumference Up to $0.5 \mathrm{~cm}-1 \mathrm{~cm}$ increase in circumference

$5^{\text {th }} \quad$ No swelling

day Below $0.5 \mathrm{~cm}$ increase in circumference Up to $0.5 \mathrm{~cm}-1 \mathrm{~cm}$ increase in circumference

\begin{tabular}{l|l|l|l|l|l} 
Trail & \multicolumn{3}{|l|}{ Control } & Z $\$$ & $p$ \\
\hline Count & Percent & Count & Percent & & \\
\hline 7 & 35.0 & 8 & 40.0 & 0.09 & 0.926 \\
\hline 13 & 65.0 & 10 & 50.0 & & \\
\hline 0 & 0.0 & 2 & 10.0 & & \\
\hline 20 & 100.0 & 20 & 100.0 & 0 & 1.000 \\
\hline 0 & 0.0 & 0 & 0.0 & & \\
\hline 0 & 0.0 & 0 & 0.0 & & \\
\hline
\end{tabular}

Table 14: Comparison of Effectiveness of Itching Itching

$3^{\text {rd }}$ day

\begin{tabular}{|l|}
\hline No itching \\
\hline Occasional itching \\
\hline No itching \\
\hline Occasional itching \\
\hline
\end{tabular}

eness of Itchi

\begin{tabular}{|l|}
\hline Trail \\
\hline Count \\
\hline 17 \\
\hline 3 \\
\hline 20 \\
\hline 0 \\
\hline
\end{tabular}

\begin{tabular}{|l|l|}
\hline Percent \\
\hline 85.0 \\
\hline 15.0 \\
\hline 100.0 \\
\hline 0.0 \\
\hline
\end{tabular}

0.0

\begin{tabular}{|l|l|}
\hline Contro \\
\hline Count \\
\hline 13 \\
\hline 7 \\
\hline 20 \\
\hline 0 \\
\hline
\end{tabular}

\begin{tabular}{|c|c|c|}
\hline & $\mathrm{Z} \$$ & $\mathrm{p}$ \\
\hline Percent & & \\
\hline 65.0 & \multirow[t]{2}{*}{1.44} & \multirow[t]{2}{*}{0.149} \\
\hline 35.0 & & \\
\hline 100.0 & \multirow[t]{2}{*}{0} & \multirow[t]{2}{*}{1.000} \\
\hline 0.0 & & \\
\hline
\end{tabular}

Mann-Whitney U test was used to compare the efficacy in relieving pain, erythema, swelling and itching between groups. On day 3, 25 percent patients experienced a decrease of one grade pain and 60 percent experienced a reduction of 2 grade pain in trial group. The decrease of 1 grade pain and 2 grade pain in control group was 35 percent and 45 percent. MannWhitney $U$ test showed that $(p>0.05)$ the decrease in pain between groups is not significant at 0.05 level. In short, the intervention in trial and control group is effective in relieving pain, but when compare the efficacy of treatment, the intervention in trial group and control group is equally effective in reducing pain (Table no.11). On fifth day, in trial group percentage of relief obtained was $100 \%$ and in control group percentage of relief obtained is $100 \%$. P value obtained is 1.000 ( $p>0.05$ ) which shows result is statistically insignificant. We can conclude the group are equally effective in relieving erythema (Table no.12). On fifth day, in trial group percentage of relief obtained was $100 \%$ and in control group percentage of relief obtained is $100 \%$. P value obtained is $1.000(\mathrm{p}>0.05)$ which shows result is statistically insignificant. We can conclude the group are equally effective in relieving swelling (Table no. 13). On fifth day, in trial group percentage of relief obtained was $100 \%$ and in control group percentage of relief obtained is $100 \%$. $P$ value obtained is $1.000(p>0.05)$ which shows result is statistically insignificant. We can conclude both the group are equally effective in relieving itching. (Table no.14).

\section{DISCUSSION}

Probable mode of action of Kushmanda Beejadi Lepa Yoga

Kushmandabeejadi lepa choorna is a lepa yoga mentioned in Kriyakoumudi under Keetadi visha prakara$n a$ for treatment of wasp sting. This yoga consists of only two ingredients- Kushmanda beeja and Haridra. Kushmanda has got Madhura rasa, Laghu guna, Ushna virya and Tridoshahara property. Madhura rasa is Vata-pithahara, Vishahara and Varnya. Laghu guna possess Srothoshodhana and Ropana properties. Ushna guna being Vata-kaphahara helps in reducing the pain, swelling and itching produced by wasp sting. By virtue of these properties such as Vishahara, Srothoshodhana and Ropana, the external signs and symptoms produced by poisonous bites can be pacified. Haridra is Katu Tikta rasa, Ruksha guna, Ushna virya and Kapha-pithahara. Katu rasa acts as Kanduhara, Krimihara and Sophahara. It pacifies Kapha and helps in Srotovivarana. Tikta rasa possess Krimihara, Vishahara and Pitha-kaphahara properties. Ruksha guna helps in reducing Sopha. Ushnaguna being Vata-kaphahara helps in reducing the pain, swelling and itching. It is an excellent Vishahara dravya which has been proven since years. In Kushmandabeejadi lepa choorna, these two ingredients are 
mixed in equal proportion which gives a synergetic action in the treatment of poisonous symptoms produced by wasp sting.

\section{CONCLUSION}

Sigrupnarnavadi lepa has been practically found to be effective in all types of Keetavisha. But the number of ingredients in Sigrupunarnavadi lepa makes it a costly preparation which invites for the need for simpler preparation. Kushmandabeejadi lepa yoga mentioned in Kriyakoumudi chapter Keetadi vishaprakarana is indicated for wasp sting. Kushmandabeejadi lepa is a simpler preparation which contains only two ingredients i.e., Kushmandabeeja and Haridra. In this study both the treatments were found to be effective. Both the lepa yogas were equally effective in managing the four parameters i.e., pain, swelling, erythema and itching. No complications or adverse drug reactions were noted during the treatment period.

\section{REFERENCES}

1. Kalyanimath Gurusiddeswar J, H. T. Chaitra, A conceptual note on vishaghnalepa, IAMJ, 1(6), 2013, ISSN 23205091, p:61-68

2. Acharya Vagbhata, Astanga Hridayam, Arunadatta Sarvangasundara, Hemadri Ayurveda Rasayanam, edited by Pt. Bhishagacharya Harshastri Paradkarvaidya, Varanasi, Chaukhambha publications 2009, 37/ 2728,p:916

3. Dr. KumariUsha P.K et.al- Open clinical trial on the mode of administration of Sigrupunarnavadi lepa choorna in the treatment of sasophakeetavisha, VPSV Ayurveda College Kottakkal, 2005

4. VM Kuttykrishnan Menon, Kriyakoumudi 1st edition, Kottayam Kerala sahityapravartaka co- operative society ltd.1986.pg 659

5. Kaiyyadeva Nighantu, edited by P V Sharma, Varanasi, Chaukhambha publications, first edition 1979, p:9697

6. Dhanwanthari Nighantu, edited by PV Sharma, Varanasi, Chaukhambha publications, fourth edition, 2005, p:48-4

7. Acharya Vagbhata, Astanga Hridayam, Arunadatta Sarvangasundara, Hemadri Ayurveda Rasayanam, edited by Pt. Bhishagacharya Harshastri Paradkarvaidya,
Varanasi, Chaukhambha publications 2009, 37/ 15, p:915

\section{Source of Support: Nil Conflict of Interest: None Declared}

How to cite this URL: Vijitha Vijayan: Evaluation Of The Efficacy Of Kushmandabeejadi Lepa Against Sigrupunarnavadi Lepa In Wasp Sting - A Comparative Clinical Trial. International Ayurvedic Medical Journal \{online\} 2021 \{cited March, 2021\} Available from: http://www.iamj.in/posts/images/upload/529 535.pdf 